\title{
ANALYSIS OF CANOLA (RAPESEED) PRODUCTION COST AND INCOME IN CONTEXT OF OILSEEDS PRODUCTION SUPPORT POLICIES: A CASE STUDY FROM TRAKYA REGION OF TURKEY
}

\author{
Hasan Yilmaz' ${ }^{1}$ Buse Avkiran ${ }^{2}$
}

*Corresponding author E-mail: hasanyilmaz@isparta.edu.tr

A R T I C L E I N F O
Review Article
Received: 18 December 2019
Accepted: 30 April 2020
doi:10.5937/ekoPolj2002483Y
UDC 665.3/.6[338.5:657.212
(560 Trakija)

Keywords:

Canola, Oilseed, Support

Policies, Production Cost, farmer's income

JEL: $Q 18$

\begin{abstract}
A B S T R A C T
The study aimed to analysis the cost and income of canola production in the context of support policies to oilseeds production in the Trakya region of Turkey. In this study, the average production costs of canola were calculated as 600.13 US\$ ha-1. Gross profit and net profit excluding support payments were found as 515.98 and 310.32 US\$ ha-1, respectively. It was determined that the gross profit and net profit including support payments were found to be 921.37 and 715.72 US \$ ha-1. It was calculated that the share of supports is $44 \%$ in gross and $56.64 \%$ in net profits. The results indicated that the supports of diesel oil, fertilizer, certified seed usage and premium support have important increasing effects on farmer income and decreasing costs in canola production. As a result, it can be said that with the support policies applied in canola production, important increases have occurred in canola cultivation areas and production in Turkey. In order to have an efficient oilseed support policy, farmer's extension service should develop various programs regarding sustainable canola production practices to educate farmers.
\end{abstract}

(C) 2020 EA. All rights reserved.

\section{Introduction}

Canola refers to a cultivar of either rapeseed (Brassica napus L.).Canola is an important edible vegetable oilseed crop in the world. Its seeds are used to produce edible oil which is suitable for consumption by humans and livestock (Monjezi and Zakidizaji, 2012; Suzer, 2015). The rapeseed oil content in the seed ranges from $38 \%$ to $48 \%$ and protein content ranges from $16 \%$ to $24 \%$. The oil is also suitable for biodiesel use.

1 Hasan Yılmaz, Full Professor, Isparta University of Applied Sciences, 32260, Isparta, Turkey, +90 (246) 21185 99, E-mail: hasanyilmaz@isparta.edu.tr, ORCID ID (http://orcid. org/0000-0002-0487-8449)

2 Buse Avkiran, Master Student, nstitution, Isparta University of Applied Sciences, 32260, Isparta, Turkey, +90 (246) 21185 99, E-mail: buseavkran@gmail.com, ORCID ID (http:// orcid.org/0000-0001-9511-0074)

http://ea.bg.ac.rs 
Rapeseed production in the world ranks second following the soybean. According to FAO in 2016, canola production in the world was $73,776,943$ ha area. In the same year, the canola production in the world was 43705,654 tons. The most important share in production belongs to Canada $(21.08 \%)$, China (20.02\%), India (10.68\%), Germany (8.47\%), France (7.49\%), Australia (5.19\%) and Poland (4.44\%) (FAOSTAT, 2017). Because of the increase in population, vegetable oil seed production cannot meet the vegetable oil demand in Turkey. Therefore, Turkey has been dependent on the importation of vegetable oil seeds to meet this demand (Unakitan and Kumbar, 2010). Growing enough oil seed crops in Turkey, it is possible with increasing yield, planting areas and introducing into crop rotation new alternative oil seed crops like rapeseed. Increasing rapeseed production in Turkey will support the biodiesel industry to get the best quality vegetable oil to produce renewal, alternative fuel sources instead of imported diesel-fuel.

The winter type rapeseed can be grown Trakya, Marmara and the Black Sea, whereas spring types can be grown in the Mediterranean, Aegean and Southeast Anatolian region of Turkey. Rapeseed is very useful in crop rotation with cereals for decreasing root diseases, increasing soil organic matter and sustainable agriculture. It allows growing the double-crop in irrigated soil conditions because of the early harvest. The long flowering of rapeseed plants in the early spring help to honey bees for collecting pollen.

The Turkish government began supporting oilseeds production in 2001. The government of Turkey pays a premium to producers for oilseeds, fertilizer and diesel support per $\mathrm{kg}$ and certified seed usage support per hectare. With the support policies applied in canola production, important increases have occurred in canola cultivation areas and production in Turkey. As a matter of fact, Turkey's canola cultivation area which was 82 hectares in 2000, increased to 35,453 hectares in 2016 with oil seeds production supports. The total canola production increased around 668 fold from 187 tons to 125.000 thousand tons during the 2000-2016 periods (TURKSTAT, 2017). Trakya region has provided to $39 \%$ of canola production in Turkey.

The oilseed crops are the basic source of nutritional substance for consumers. For this reason, governments resort to oilseed production supports for both stabilizing farmers' incomes and protecting consumers. Oilseed production supporting tools used in the context of agricultural policies, interventions, government decisions finally effect on national welfare through effecting a big mass of producers, oilseed production, food self-sufficiency of the country, budget, producers income, resource uses and consumers expenditures. It is clear that investigating the effects of oilseed production policies on the income of farmers in canola growing and making more realistic decisions according to the results of those investigations in Turkey where the efficiency of oilseed production supporting policies discussed in the last years. There is limited available information about this subject. There is a need for this study to fill the gap. This study aimed to analyse the effects on farmer's income of oilseed support policies in canola production in the Trakya region of Turkey. 


\section{Literature Review}

Many studies investigated, support of agricultural production and the effects of these supports on agricultural production, farmer's welfare and reflection to producer income in various countries and Turkey. However limited research examined the effects of canola production support policies on farmers' incomes in the world and Turkey. In the study, information on studies especially related to the research carried out in various countries is provided.

Chau and de Gorter (2005) concluded that the effect of income supports on aggregate output could be minimal only if the output of marginal farms is small. Ören and Bahadir (2005) indicated that the supports to livestock sector are mainly provided by the protection relatively high domestic cost prices against to abroad in Turkey, in developed countries such as the EU and the US, various domestic support tools are used beside border measurements. Yilmaz et al., (2006) showed that policy changes have differently influenced farmers regarding their farm sizes. As farm size increased it was observed that farmers benefited more from agricultural support. Yilmaz et al., (2008) showed that there is a significant relationship between the farmers receiving and not receiving direct income support, considering farmers' age, membership of cooperative agricultural, gross product value, the average size of farmland, size of arable land and the size of owned land.

Strelecek et al., (2009) concluded that the subsidies applied according to the type of production might affect production diversity. Benni et al.,(2012) indicated that the influences of agricultural policy changes on income risks are also empirically assessed at different spatial scales. Semerci (2013) concluded that premium supports are inefficient in increasing sunflower cultivation area and production. However it also concluded that it has an important role in producer income and the determination of the market price. Munćan and Božić (2013) founded that the measures of direct support in field crop production to be simulative, especially to small producers who were noted to apply optimal agricultural practices. Dorward and Morrison (2015) examined the effects of agricultural supports on food security and poverty reduction. Drabenstott (2015) urged an answer to the question of whether agricultural support payments would promote rural economic growth.

Semerci, (2016) confirmed that agricultural support amount per farm in Turkey is 4.3 times lesser than the EU average. Also, agricultural supports do product cost reducing and producer revenue increasing effect. Devadows et al. (2016) showed that the contrary to the existing literature, removal of direct payments augments productivity while removal of price supports does not impact productivity, and direct payments can lead to larger production distortions than price supports under certain conditions. Lajqi et al., (2017) showed that both a higher economic and financial sustainability of good agricultural practice for conventional farming, while the opposite was true in terms of employment effects of intervention programs. 
Celik Ates et al., (2017) revealed that small-scale farmers were unable to use the support provided by the policies; as a consequence, many of them were unable to cultivate their land and had to migrate. In general, stated that significant social and economic changes did occur in rural areas. However, they emphasized that these changes were to the detriment of small-scale farmers and instead favoured farmers operating on the large scale. In this study, it is examined the effect on production cost and farmers income in canola farming of oilseed production support policies in Turkey.

\section{Materials and methods}

Description of the research area: The study area, Kesan is a district of Edirne Province, is located in the Trakya region, Turkey. Edirne lies between $40^{\circ} 30^{\prime}$ and $42^{\circ} 00^{\prime}$ North latitude and $26^{\circ} 00^{\prime}$ and $27^{\circ} 00^{\prime}$ East longitude. There is Greece to the East, Bulgaria to the Northeast, and the Aegen Sea to the South. Kesan is located on the eastern side of a plain extending up to the Meric River in its west. Its total area is $1087 \mathrm{~km}^{2}$. The Marmara type of the Mediterranean climate is dominant in District. The yearly average temperature is $13.69^{\circ} \mathrm{C}$. The months of autumn and winter are cold and rainy, and the summer is dry. The average amount of rainfall is $569.55 \mathrm{~mm} /$ year. The climate is milder in the region having a coast to the Saros Bay. A large part of our district is usually covered by flat land and cereal fields. As a large part of the land of the district is arable, the people do live on farming. The economy generally based on agriculture in the district, endowed with arable soil. The mainly cultivating crops are wheat, sunflower, canola, barley, corn, and rice (MP, 2005).

Sampling technique and data collection: The study was conducted in villages of Keşan district of Edirne Province, Turkey. The intentional sampling method was used to determine the village and the number of samples for each village based on canola growing activities (Karasar 1991). Data were collected mainly from primary sources by a questionnaire administered to 73 canola growers selected by simple random sampling method. The questionnaire was implemented in July- August 2016 in 12 villages were selected to represent the canola growing area.

Methods of Analysis: In this study, the total production costs and incomes were analyzed using a partial budgeting approach during the canola growing period. According to the method, production costs and returns were calculated only for the canola production. In the study, interest in total variable costs was calculated. This interest is called revolving fund interest and reflects the opportunity cost of capital invested for production. Revolving fund interest was taken as half the interest rate (4\%) applied by Turkish Republic Agricultural Bank to variable costs for crop production credits. Fixed costs included administrative costs and land rent. An administrative cost was assumed to be $3 \%$ of variable costs. This method was applied in most of the previous studies (Kiral et al., 1999; AERI, 2001). 


\section{Results and Discussion}

General characteristics of the farms: Summary of descriptive statistics and cropping pattern of the farms in the research area were given in Table 1 . The average age of the farmers was 54.08 and the average experience of farmers in canola production was 4.59 years. The average household size was 3.47 people. Farmers' average years of education was 8.49 (Table 1). The average farm size was 24.91 ha. It was found that the farms under irrigation were $36.33 \%$ of farm size and the dry land was $63.67 \%$. The average farm area of the farms was 24.91 ha of which $17.22 \%$ was devoted to canola (4.29 ha) production. The share of crop planting patterns in surveyed farms were $40.98 \%, 20.92 \%, 17.22 \%, 7.41 \%, 5.59 \%, 4.74 \%$ and $3.14 \%$ for wheat, sunflower, canola, maize, paddy, barley and oat, respectively (Table 1).

Table 1. Summary of descriptive statistics and cropping pattern in surveyed farms

\begin{tabular}{|l|c|c|}
\hline Descriptive statistics & Mean & \% \\
\hline Farmer's age (years) & 54.08 & - \\
\hline Farmer's education(years) & 8.49 & - \\
\hline Number of people in the family & 3.47 & - \\
\hline Farmer's experience (years) & 30.10 & - \\
\hline Canola growing experience (years) & 4.59 & - \\
\hline Average farm size (hectare) & 24.91 & 100.00 \\
\hline Irrigated area (ha) & 9.05 & 36.33 \\
\hline Non-irrigated area (ha) & 15.86 & 63.67 \\
\hline Owned land (ha) & 11.16 & 44.81 \\
\hline Rented land (ha) & 11.13 & 44.66 \\
\hline Shared land (ha) & 2.62 & 10.53 \\
\hline Cropping Pattern (ha) & & \\
\hline Canola & 4.29 & 17.22 \\
\hline Wheat & 10.21 & 40.98 \\
\hline Barley & 1.18 & 4.74 \\
\hline Sunflower & 5.21 & 20.92 \\
\hline Paddy & 1.39 & 5.59 \\
\hline Maize & 1.85 & 7.41 \\
\hline Oat & 0.78 & 3.14 \\
\hline
\end{tabular}

Source: Authors' calculation based on survey data

Economic analysis of canola production: Cost items of canola production are given in Table 2. In this study, the average production costs of canola were calculated as 600.13 US\$ ha- ${ }^{-1}$. Other similar studies were conducted in Iran by Taheri-Garavand et al., (2010) and in Turkey by Unakitan et al., (2010) who found that the average production costs of canola were 641.1 US\$ ha- ${ }^{-1}$ and $839.98{\text { US } \$ h^{-1}}^{-1}$, respectively.

The variable cost was the main contributor to production cost. In the study, the proportion of variable cost in total production cost was $65.73 \%$ and the fixed cost was $34.27 \%$. Labour and machine power costs were $38.71 \%$ of canola production costs. 
Soil preparation was $16.31 \%$ of total canola production costs, then respectively, harvest $(11.85 \%)$ and transport $(4.54 \%)$. The cost of machine power is more than other cost items because the diesel price is very high. It was determined that the most important cost was land rent in fixed costs $(32.30 \%)$.

The rates of input costs in the cost of total production were $24.50 \%$. Of all inputs cost, the share of seed, fertilizer, and pesticides were $2.96 \%, 13.34 \%$, and $8.19 \%$, respectively. In this study, the average cost of seed, fertilizer, and pesticides in canola production

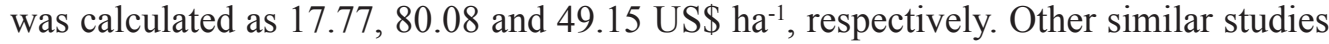
were conducted in Iran by Taheri-Garavand et al., (2010) who found that these costs were 25.3, 32.7 and 25.6 US\$ ha ${ }^{-1}$, respectively. Since the governments of Turkey give subside to certified seed usage, the cost of it was low.

Table 2. Costs of canola growing in surveyed farms (US\$ ha-1)

\begin{tabular}{|c|c|c|}
\hline Cost items & $($ US\$ ha-1) & $(\%)$ \\
\hline \multicolumn{3}{|l|}{ 1. Labour and machine power costs } \\
\hline $\begin{array}{l}\text { Soil preparation } \\
\text { First plugging }(50,25 \text { US\$) } \\
\text { Second plugging }(22,47 \text { US\$) } \\
\text { Harrowing }(13,93 \text { US\$) } \\
\text { Deep Harrowing }(11,21 \text { US\$) }\end{array}$ & 97.86 & 16.31 \\
\hline Sowing & 16.90 & 2.82 \\
\hline Labour of fertilizing & 9.42 & 1.57 \\
\hline Labour of pesticide application & 9.75 & 1.62 \\
\hline Harvest & 71.13 & 11.85 \\
\hline Transport & 27.25 & 4.54 \\
\hline Total & 232.30 & 38.71 \\
\hline \multicolumn{3}{|l|}{ 2. Input costs } \\
\hline Seed & 17.77 & 2.96 \\
\hline Fertilizer & 80.08 & 13.34 \\
\hline Pesticide & 49.15 & 8.19 \\
\hline Total & 147.01 & 24.50 \\
\hline 3. Interest on total variable costs & 15.17 & 2.53 \\
\hline A-Total variable costs $(1+2+3)$ & 394.48 & 65.73 \\
\hline Administrative costs $\left(\mathrm{A}^{*} 0.03\right)$ & 11.83 & 1.97 \\
\hline Land rent & 193.82 & 32.30 \\
\hline B-Fixed costs & 205.65 & 34.27 \\
\hline C-Total costs $(A+B)$ & 600.13 & 100.00 \\
\hline
\end{tabular}

Source: Authors' calculation based on survey data

Effects of oilseed production support policy on farmer's income in canola growing: Gross profit, net profit and relative return for canola production excluding support payments are given in Table 3- Part A. The approximate price received by the

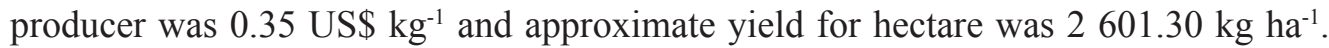
Therefore, gross production value from canola production was $910.46 \mathrm{US} \$ \mathrm{ha}^{-1}$. Then by subtracting the variable cost from gross production value, gross profit from canola production was calculated. The gross profit from canola production was determined as 
515.98 US\$ ha ${ }^{-1}$. It is an important indicator that determines the competitive edge of the production activity of the farm in terms of insufficient resources use. In other words, it is and indicator that showing the enterprise's success (Erkus et al. 1995).

Net profit was calculated by subtracting the total cost from gross production value.

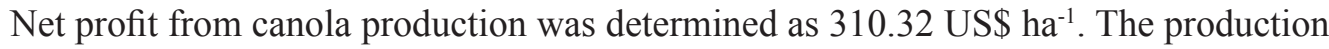
cost for one $\mathrm{kg}$ canola was calculated as $0.23 \$ \mathrm{~kg}^{-1}$. The relative return was calculated by dividing gross production value by total cost (Rehber 1993; Erkus et al., 1995). Relative return is another indicator that measures the success of a farm enterprise. Relative return shows return obtained for every one unit invested. Thus values lower than one means that total production cost exceeds gross product value leading a loss. If the value is larger than one, it indicates that the enterprise is profitable. Relative return from canola production was determined as 1.52. A similar study was conducted in Iran by Taheri-Garavand et al., (2010) and Unakitan et al., (2010) who found that relative returns were 1.86 and 2.09 , respectively.

Gross profit, net profit and relative return for canola production including support payments are given in Table 3-Part B. In 2016, canola producers received US\$ 30.22 $\mathrm{ha}^{-1}$ towards the cost of fertilizer+diesel oil, US\$ $10.99 \mathrm{ha}^{-1}$ for certificated seed support. The premium support for canola farmers in 2016 was US\$ $364.18 \mathrm{ha}^{-1}$. It is estimated that the whole supports for canola production amount to US\$ $405.39 \mathrm{ha}^{-1}$.

It was by taken into consideration the effects of the support payments on canola gross production value, gross profit and net profit reaches up to the level of $1315.85,921,37$ and 715,72 US\$ ha-1. The share of supports payments in gross profit and net profit value of which was calculated in consideration of support payments are $44 \%$ and $56.64 \%$. These rates reveal the contribution and importance of support payments on gross profit, net profit and gross production value of canola production.

Table 3. Canola Production Cost and Income in Context of Support Payments

\begin{tabular}{|c|c|}
\hline Canola farmer's income, excluding support payments ( Part A) & \\
\hline A. Canola Yield, $\mathrm{kg} \mathrm{ha}^{-1}$ & 2601.30 \\
\hline B. Sales price, US\$ kg-1 & 0.35 \\
\hline C. Gross production value, US\$ ha-1 $\left(\mathrm{A}^{*} \mathrm{~B}\right)$ & 910.46 \\
\hline D. Variable costs value, US\$ ha ${ }^{-1}$ & 394.48 \\
\hline E. Total cost, US\$ ha-1 & 600.13 \\
\hline F. Total cost, US\$ kg-1 (E/A) & 0.23 \\
\hline G. Gross profit, US\$ ha-1 $(C-D)$ & 515.98 \\
\hline H. Net profit, US\$ ha-1 $(\mathrm{C}-\mathrm{E})$ & 310.32 \\
\hline I. Relative return $(\mathrm{C} / \mathrm{E})$ & 1.52 \\
\hline \multicolumn{2}{|l|}{ Canola farmer's income, including support payments ( Part B) } \\
\hline A. Canola Yield, $\mathrm{kg} \mathrm{ha}^{-1}$ & 2601.30 \\
\hline B. Sales price $/{\mathrm{US} \$ \mathrm{~kg}^{-1}}^{-1}$ & 0.35 \\
\hline C. Premium support $/{\mathrm{US} \$ \mathrm{~kg}^{-1}}^{-1}$ & 0.14 \\
\hline D. Fertilizer+diesel oil support/US\$ ha ${ }^{-1}$ & 30.22 \\
\hline E. Certified seed usage support / US\$ ha ${ }^{-1}$ & 10.99 \\
\hline
\end{tabular}




\begin{tabular}{|l|c|}
\hline F. Total support/US\$ ha-1 ((A*C)+D+E) & 405.39 \\
\hline G. Gross production value, US\$ ha' ${ }^{-1}(\mathrm{~A} * \mathrm{~B})+\mathrm{F}$ & 1315.85 \\
\hline H. Variable costs value/US\$ ha & -1 \\
\hline I. Total cost, US\$ ha-1 & 394.48 \\
\hline J. Gross profit, US\$ ha-1 $(\mathrm{G}-\mathrm{H})$ & 600.13 \\
\hline K. Net profit, US\$ ha-1 $(\mathrm{G}-\mathrm{I})$ & 921.37 \\
\hline L. Share of supports in gross profit (\%) & 715.72 \\
\hline M. Share of supports in net profit (\%) & 44.00 \\
\hline
\end{tabular}

Source: Authors' calculation based on survey data

Factors influencing on canola production of farmers: Table 4 shows the Factors influencing on canola production of farmers. The research results showed that the most important factors influencing canola production of farmers were high income, easy marketing, favorable climatic conditions, effortless canola farming, production supports and dealing with beekeeping. (Table 4).

Table 4. Factors influencing canola production of farmers

\begin{tabular}{|l|c|c|}
\hline Reasons & $\mathbf{N}$ & $\mathbf{\%}$ \\
\hline Income is high & 51 & 69.86 \\
\hline There is no marketing problem & 37 & 50.68 \\
\hline Wild pigs cannot harm canola & 30 & 41.10 \\
\hline Climate conditions are very suitable for canola growing & 15 & 20.55 \\
\hline Government supports are too much for canola production & 15 & 20.55 \\
\hline Canola growing is very easy & 11 & 15.07 \\
\hline I engage beekeeping & 3 & 4.11 \\
\hline
\end{tabular}

Source: Authors' calculation based on survey data, *Multiple responses allowed. N $=73$

\section{Conclusions}

Canola growing is an important part of oilseed production in Turkey. Besides canola oil, it would be used for biodiesel and bioethanol production, which gives the alternative source of income and market opportunities to farmers. It can be said that the implemented supports policies and encouragement have provided remarkable increases in oilseed production in Turkey. However, the amount of vegetable oil produced in Turkey has not met with country demands. The extending of oilseed crops growing has become a necessity to increase production and reduce imports of oilseed crops in Turkey. In this study, we analyzed the effects on farmer's income of oilseed support policies in canola production in the Trakya region of Turkey. The primary data used in the study were obtained via the survey from 73 farmers engaged in canola growing in the Kesan district of Edirne Province in the Trakya region of Turkey. Gross profit for canola production excluding and including support

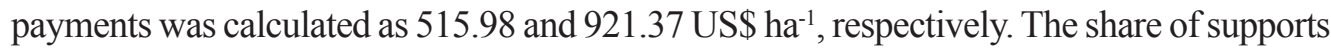
payments in gross profit and net profit value of which was calculated in consideration of support payments were $44 \%$ and $56.64 \%$. Based on the findings of the study, it can be said that the supports of diesel oil, fertilizer, certified seed usage and premium support have significant increasing effects on farmer income and decreasing costs in canola production. 
As a result, canola production support policies should be continued because Turkey needs to increase canola oil seeds production by using intensive modern crop growing techniques. Therefore, it can be said that as a significant oilseed crop, to increase canola production in Turkey, supporting canola production with the proper agricultural political tools ensuring the sustainability of the crop is essential for the farmers.

\section{Acknowledgements}

The authors thank the Scientific and Technological Research Council of Turkey (TÜBİTAK BİDEB - 2209) for financial support.

\section{Conflict of interests}

The authors declare no conflict of interest.

\section{References}

1. AERI, (2001). Input Use and Production Costs for Important Crops in Some Regions of Turkey. [Türkiye'de Bazl Bölgeler Için Önemli Ürünlerde Girdi Kullanımı ve Üretim Maliyetleri]. Agricultural Economics Research Institute, Research report, Publication No. 64, 248, Ankara-Turkey.

2. MP, (2005). Master Plan (MP), Provincial Agriculture and Rural Development Master Plan. Retrieved from https://www.tarim.gov.tr/SGB/Belgeler/Master/ edirne.pdf. (May 15, 2017).

3. Benni, N., Finger, R., \& Mann, S. (2012). Effects of agricultural policy reforms and farm characteristics on income risk in Swiss agriculture. Agricultural Finance Review, 72 (3), 301-324.

4. Celik Ates, H., Yilmaz, H., Demircan, V., Gul, M., Ozturk, E., \& Ormeci Kart, M.C. (2017). How did post-2000 agricultural policy changes in Turkey affect farmers? - A focus group evaluation. Land Use Policy, 69, 298-306.

5. Chau, N.H., \& Gorter. H. (2005). Disentangling the Consequences of Direct Payment Schemes in Agriculture on Fixed Costs, Exit Decisions, and Output. American Journal of Agricultural Economics, 87, 1174-1181.

6. Devadoss, S., Gibson, M.J., \& Luckstead, J. (2016). The Impact of Agricultural Subsidies on the Corn Market with Farm Heterogeneity and Endogenous Entry and Exit. Journal of Agricultural and Resource Economics, 41(3), 499-517

7. Dorward, A. \& Morrison, J. (2015). Heroes, villains and victims: agricultural subsidies and their impacts on food security and poverty reduction. Available at: https://eprints.soas.ac.uk/16754/1/Subsidies $\% 20$ chapter $\% 20 \% 20$ Dorward $\% 20$ Morrison\%20posted.pdf. (May 12, 2018).

8. Drabenstott, M. (2015). Do farm payments promote rural economic growth?. $\mathrm{Ag}$ Decision Maker, 9 (6). http://lib.dr.iastate.edu/agdm/vol9/iss6/2. (April 18, 2018). 
9. Erkus, A., Bülbül, M., Kıral, T., Aç1l A. F., \& Demirci, R. (1995). Agricultural Economics [Tartm Ekonomisi]. Ankara University Faculty of Agriculture Pres, Ankara, Turkey

10. FAOSTAT (2018). Crop statistics, the statistics division of the Food and Agriculture Organization (FAO). Retrieved from http://faostat3.fao.org/download/Q/QC/E. (September 20, 2017).

11. Karasar., N. (1991). Scientific research method [Bilimsel Araştırma metodu]. 4th ed. Ankara, Turkey

12. Kiral, T., Kasnakoglu H., Tatlidil, F., Fidan, H \& Gundogmus, E. (1999). Data Base Guide and Production Cost Methodology for Agricultural Products. [Tarimsal Ürünler için Maliyet Hesaplama Metodolojisi ve Veritabanı Rehberi]. Agricultural Economics Research Institute, Publication no: 37, Ankara-Turkey.

13. Lajqi, S., Thaqi, M., Kaçiu, K., Bytyqi, H., \& Krasniqi, B.A. (2017). Impact of Agricultural Intervention Programs on Income and Employment: Evidence from Vegetable Sector in Kosovo. Economic Thought and Practice (Ekonomska misao i praksa), (2): 561-592.

14. Monjezi, N., \& Zakidizaji., H. (2012). Energy and Economic Analysis of Canola Production in Iran a Case Study: Khuzestan Province. Research Journal of Applied Sciences, Engineering and Technology, 4 (3), 227-231.

15. Munćan, P., \& Božić, D. (2013). The Effects of Input Subsidies on Field Crop Productıon in Serb1a. Economics of Agriculture, 60 (3), 585-594.

16. Ören, M.N., \& Bahadir, B. (2005). Livestock Policies and Policy Transfers in Turkey and OECD Countries, [Türkiye'de ve OECD Ülkelerinde Hayvansal Ürün Politikaları ve Bu Politikalar Sonucu Ortaya Çıkan Transferler]. Hayvansal Üretim, 46(1), 1-7.

17. Rehber, E. (1993). Agricultural Management and Planning [Tarımsal işletmecilik ve Planlama]. Uludag University, publication no:84, Bursa, Turkey

18. Semerci, A. (2013). The Effects of Agricultural Subsidies on Sunflower Cultivation and Farmers' Income: Evidence from Turkey. Pakistan Journal of Agricultural Sciences. 50 (1), 139-145.

19. Semerci, A. (2016). Effects of agricultural supports on farmer's revenue and product costs: the case of Turkey. Custos e @gronegócio on line, 12 (3), 71-96.

20. Strelecek, F., Lososova, J. \& Zdenek, R. (2009). Comparison of agricultural subsidies in the Czech Republic and in the selected states of the European Union. Agricultural Economics Czech, 55, 519-533.

21. Suzer, S. 2015. Effects of Plant Nutrition on Canola (Brassica napus L.) growth. Trakya University Journal of Natural Sciences, 16(2), 87-90.

22. Taheri-Garavand, A., Asakereh, A., \& Haghani, K. (2010). Energy elevation and economic analysis of canola production in Iran a case study: Mazandaran province. International Journal of Environmental Sciences, 1(2), 236-242. 
23. TURKSTAT. (2016). Crop Production Statistics, Turkish Statistical Institute. Retrieved from http://tuikapp.tuik.gov.tr/bitkiselapp/bitkisel.zul.

24. Unakitan, G., Hurma, H. \&Yilmaz, F. (2010). An analysis of energy use efficiency of canola production in Turkey. Energy 35,3623-3627.

25. Unakitan, G., \& Kumbar, N. (2010). Factor Demand Analysis for Canola Production in Turkey. New Medit, 4, 59-64.

26. Yilmaz, H., Demircan, V., \& Dernek. Z. (2006). A Research on farmers' opinions about effect of agricultural policy implemented after 2000 in Turkey. [Türkiye de 2000 Yılı Sonrası Uygulanan Tarım Politikalarının Yansımalarına İlişkin Üretici Görüşleri Üzerine Bir Araştırma]. The Journal of Suleyman Demirel University Faculty of Agriculture, 1 (2), 62-70.

27. Yilmaz, H., Demircan. V., \& Dernek, Z. (2008). Direct Income Support Implementation in Turkish Agriculture - Evaluation of Farmers in Isparta Province-. [Türkiye Tarımında Doğrudan Gelir Desteği Uygulamaları-Isparta İli Üreticileri Açısından Bir Değerlendirme], Doguş Üniversitesi Dergisi, 9 (2), 248-265. 